\title{
The zoogeography of Polychromopbilus and description of a new species of a Gregarine (Lankesteria galliardi)
}

\author{
par P. C. C. GARNHAM * \\ Imperial College of Science Field Station, Ascot, Berkshire, England
}

\section{Résumé}

La large répartition de Polychromophilus spp. dans l'Ancien Monde et sa rareté dans le Nouveau Monde, sont discutées; de nouvelles localisations et des redescriptions sont données. Une nouvelle espèce de Grégarine chez les Nyctéribiies est décrite et nommée Lankesteria galliardi, en hommage au Professeur Henri Galliard.

\section{Summary}

The wide distribution of Polychromophilus spp. in the Old World and the rarity in the New World are discussed, and new records and redescriptions are given. A new species of a Gregarine parasite in Nycteribiid flies is described and named in honour of Professor Henri Galliard.

(*) Emeritus Professor of Medical Protozoology (University of London). 
Malaria parasites of bats have continued to interest zoologists ever since the day when Grassi suggested to his younger colleague, Dionisi, that he should abandon the study of the malaria parasites of man and examine instead those of bats. Dionisi responded enthusiastically, realising the great advantages which a parasite of small mammals could offer for malaria research. Within a year he succeeded in finding two species of a pigmented haemosporidian and a non-pigmented piroplasm in bats near Rome. Dionisi (1899) recognised that the former did not belong to the true malaria parasites and probably possessed a different mode of multiplication; he accordingly placed them in a new genus, Polychromophilus. Wenyon (1926) removed these parasites to the genus Plasmodium, but the elucidation of their full life cycle by Mer and Goldblum (1947) and others, enabled the writer (Garnham 1953) to restore them to the original genus, in the family Haemoproteidae.

One of the next records of the bat parasites was from Indo-China, and it was the memory of this observation by Vassal (1907) that suggested to me the suitability of this subject for the Livre Jubilaire, as Professor Henri Galliard is specially notable for his prolonged and interesting researches in that territory. Moreover, his deep appreciation of the host-parasite-vector problem makes the zoogeography of these parasites a particularly appropriate subject. (The writer first learnt the importance of such considerations in 1931 from son maitre, Henri Galliard, during the Cours de Malariologie in the Rue de l'Ecole-de-Médecine).

In this communication, I intend to limit my observations to the genus Polychromophilus, but first, I must briefly mention the other malaria parasites (sensu latu) of bats, because, in practice, it is difficult enough to distinguish the parasites belonging to different genera, let alone different species of the same genus.

The haemosporidian parasites of bats fall into at least 4 genera, Plasmodium, Hepatocystis, Nycteria and Polychromophilus. Plasmodium is limited to two African species ( $P$. roussetti and $P$. voltaicum) and is usually easily identified by the presence of schizonts in the blood, which are absent in the species belonging to the other three genera. Hepatocystis is confined to the fruit bats and has a wide distribution in tropical Asia and Africa. Nycteria appears to occur only in insectivorous bats in tropical Africa, but further surveys may show that it occurs elsewhere, and some reports of Polychromophilus in these bats may have been misidentifications.

Plasmodium spp., Hepatocystis spp. and Nycteria spp. are thus seen to be parasites of bats only of the Old World. Polychromophilus was thought to have an equally restricted distribution but later observations have shown that parasites belonging to this genus also occur in the New World, though probably to a limited extent.

\section{Outline of life history of Polychromopbilus}

The blood stages of Polychromophilus, like those of all parasites in the Haemoproteidae are confined to gametocytes. The youngest forms resemble typical malaria «rings» in erythrocytes; the vacuole disappears with growth, pigment appears and sexually differentiated parasites develop. Their oval shape, though not inva- 
riable, is a striking feature. Exflagellation of the microgametocyte is characteristically difficult to elicit in a humid chamber.

The course of sporogony has been briefly described by Mer and Goldblum : it takes place in nycteribiid flies (Penicillidia spp. in Israel) in which oocysts grow on the midgut and stumpy sporozoites invade the salivary glands. Further details of the development of the parasite in these flies are given below, and the facility with which these phases are demonstrable is rather striking. The ectoparasitic nature of the vector is of course the explanation; one does not have to search far afield for the transmitter.

Schizogony of the parasite in the vertebrate host is much more elusive, and has only been observed in detail by the Israeli workers. Asexual development apparently occurs in a variety of organs and in different types of cells. The final form of schizogony settles down in the Kupffer cells of the liver where small schizonts grow. Larger bodies have been seen in the spleen, lungs and other organs, and as early as 1907, Schingarev described the transport of unpigmented schizonts by macrophages in the blood. The relationship between these asexual stages is still undefined. The exoerythrocytic schizonts of Nycteria (Garnham and Heisch 1953) of insectivorous bats are highly characteristic in morphology and constant in site of development in the parenchyma cells of the liver, and it is unlikely that they are attributable to stages of Polychromophilus.

The specific identity of Polychromophilus has always been a problem, initiated by Dionisi's classification of Italian material into Po. melanipherus and Po. murinus. The former was thought to be allied to the human quartan parasite and the latter to the benign tertian. The morphological distinctions are slight, and for the sake of convenience (and until full details of the life history are discovered) the writer (1961) suggested that the designation Po. melanipherus should be restricted to infections in the type host - Miniopterus schreibersii (and other species of this genus) while the name Po. murinus should be used for infections in all other insectivorous bats. Fortunately, there has been little tendency to give separate names to parasites found in new hosts or regions, though a few have been described from Asia, and more recently the writer and his colleagues considered that a New World parasite from the Amazonian region was sufficiently remote from the Old World to warrant a new name. With these exceptions, such conservative treatment has been applied in this paper.

\section{Records in Old World}

\section{Europe.}

Po. melanipherus. The type locality of this parasite is the Roman Campagna and the type host, Min. schreibersii. Infections are common elsewhere in Italy, e.g. Maccarese, Fiumicino. It also occurs in Russia (Vitebsk). 
Po. murinus. The type locality of this species is again the Roman Campagna and the host is Vespertilio murinus. It is common in these bats and other vespertilionids elsewhere in Italy and Moriggi found a high incidence of the parasite (thought to be mixed with Po. melanipherus) in Rhinolophus ferrumequinum in Brescia. It has also ben reported from Vitebsk in Russia in Myotis daubentoni; from near Bournemouth in England in pipistrelles (though subsequent searches 50 years later in this locality by the writer proved negative); from Utrecht in Holland in Myotis spp.

Asia.

Po. melanipherus. Mer and Goldblum made their fundamental discovery of the life history of bat malaria parasites, in bats collected in caves above the Plain of Sharon in Israel. Both species of Polychromophilus are common in this part of the Middle East.

Po. murinus. As in Israel, the parasite of Myotis myotis from Lake Van in Turkey is probably to be referred to this species, although it was identified originally by the writer as Po. melanipherus. Similarly, the parasite in Pipistrellus abramus from Vietnam was designated subspecies monosoma of Po. melanipherus, but is better placed under Po. murinus. Another early record came from Portuguese India, where de Mello and de Sa (1916) described as Plasmodium mackiei a parasite in the erythrocytes of Myotis muricola. Their crude illustrations and text suggest that the organism underwent schizogony, but probably the divided chromatin represented fragmentation of the nucleus of the microgametocyte. They called attention to the ovoid shape of the gametocytes. If this parasite is considered worthy of subspecific identity, its name would be Po. murinus mackiei (de Mello and de Sa, 1916). Malaria parasites of Hipposideros bicolor (and in H. armiger and $H$. diadema) in Malaya were found by Eyles (1962) and Dunn (1965) and were thought by the writer possibly to be a new species of Polychromophilus; later, further examples in other bats in this region were discovered by Ewers. In an expedition to Kashmir in 1970, Geoffrey le Patourel collected, on behalf of the writer, specimens from bats and such an infection is described below.

\section{Australasia.}

Po. melanipherus and murinus. The former is probably the better designation of the parasite which McGhee found in Miniopterus australis in the New Hebrides. Similarly, this is probably the better name for the parasites in Min. schreibersii in Queensland, while the species in other Australian bats, Eptesicus humilis, Nyctophilus bifax and Hipposideros semoni may be identified as Po. murinus. The latest record from Australia comes from Drew and Macmillan (1970). They found infection rates of up to $83 \%$ in Miniopterus schreibersii in New South Wales and 
$42 \%$ in Eptesicus humilis in Queensland; a single occyst was found in a nycteribiid fly, but no exoerythrocytic schizonts were detected.

\section{Africa.}

The identification of African material is complicated by the existence in that continent of Nycteria spp. in insectivorous bats, and it is difficult to assign even a generic identity to parasites in Anciaux de Faveaux' extensive collection from caves in the Congo. He tentatively named the parasites found in Min. inflatus and Min. natalensis, as Po. melanipherus; the species in the horseshoe bats were probably Nycteria congolensis. Recently, Adam (1971) has studied the parasites of insectivorous bats near Brazzaville and has been able to clarify the systematic position to some extent by the discovery of sporogonic and exoerythrocytic stages. Parasites were found in at least three species of bats of different genera (Miniopterus, Rhinolophus and Triaenops); in Min. minor exoerythrocytic schizonts of a Nycteria type were found in the lungs (Adam and Landau, 1973) and nycteribiid flies collected off these animals were frequently found to be infected with stumpy sporozoites. $\mathrm{D}^{r}$ R. Killick-Kendrick (pers. com.) had the opportunity of observing the sporozoites of the Brazzaville species, in the fresh state, after dissection of the nycteribiids, and was struck by their great motility in contrast to the feeble movements of the sporozoites of Plasmodium spp. Bray and Ashford have recently found Polychromophilus murinus in Rhinolophus in Ethiopia (see below) and have seen rare schizonts in smears of the liver.

\section{Records in New World}

A fairly large survey of bat parasites in general has been made in the New World, principally on account of Chagas' disease, but also in investigation on yellow fever, leishmaniasis and rabies. Yet the records of malaria parasites are extremely few. Polychromophilus has been reported twice from the Amazonian region, and once from California and Texas. There is an unpublished observation by V. Scorza from Venezuela. The Amazonian form was first reported by the Deanes in 1961 from Glossophaga soricina (on material collected a decade earlier) and later by the writer and his colleagues (Garnham et al. 1970) from a little further up stream and in a different genus of bats - Myotis nigricans. The parasite was given a new name (Po. deanei) on the basis of zoogeography.

The North American observations were made by Wood (1952), who briefly described infections in Antrozous pallidus and Pipistrellus hispidus. The parasite showed minor differences from the Brazilian strain and these are discussed below from a re-examination of the material by the writer.

The records from the Old and New World are summarised in Table 1. 
Table I

RECORDS OF POLYCHROMOPHILUS

\begin{tabular}{|c|c|c|c|c|c|}
\hline Place & Bat & $\begin{array}{l}\text { Polychro- } \\
\text { mophilus }\end{array}$ & Nycteribiid & $\begin{array}{c}\text { E.E. } \\
\text { schi- } \\
\text { zonts }\end{array}$ & Author \\
\hline Italy $\ldots$. & $\begin{array}{l}\text { Min. } \\
\text { schreibersii }\end{array}$ & melanipherus & - & - & Dionisi \\
\hline$»$ & $\begin{array}{l}\text { Vesp. } \\
\text { murinus }\end{array}$ & murinus & 一 & 一 & Dionisi \\
\hline$\gg$ & $?$ & $?$ & Nycteribia * & 一 & Corradetti \\
\hline$\gg$ & $\begin{array}{l}\text { Min. } \\
\text { schreibersii }\end{array}$ & melanipherus & 一 & 一 & Corradetti \\
\hline 》 & Rhinolophus & murinus & 一 & - & Moriggi \\
\hline Russia $\quad$. & $\begin{array}{l}\text { Min. } \\
\text { schreibersii }\end{array}$ & melanipherus & 一 & 一 & Schingarev \\
\hline$\gg$ & $\begin{array}{l}\text { Myotis } \\
\text { daubentoni }\end{array}$ & murinus & suspected & + & Schingarev \\
\hline England . & Pipistrellus & murinus & - & 一 & Coles \\
\hline Holland . & Myotis spp. & murinus & - & - & Goedbloed \\
\hline Israël $\ldots$ & $\begin{array}{l}\text { Min. } \\
\text { schreibersii }\end{array}$ & melanipherus & 一 & 一 & $\begin{array}{l}\text { Mer et Gold- } \\
\text { blum }\end{array}$ \\
\hline$\gg$ & Myotis spp. & murinus & Penicillidia spp. & + & $\begin{array}{l}\text { Mer et Gold- } \\
\text { blum }\end{array}$ \\
\hline $\begin{array}{l}\text { Turkey in } \\
\text { Asia .... }\end{array}$ & Myotis myotis & murinus & - & - & Garnham \\
\hline Vietnam . & Pipistrellus & monosoma & 一 & 一 & Vassal \\
\hline India $\ldots$. & $\begin{array}{l}\text { Myotis } \\
\text { muricoli }\end{array}$ & mackei & 一 & 一 & $\begin{array}{l}\text { de } \text { Mello et } \\
\text { de } \mathrm{Sa}\end{array}$ \\
\hline Malaya .. & $\begin{array}{l}\text { Hipposideros } \\
\text { spp. }\end{array}$ & murinus & 一 & 一 & Eyles et al. \\
\hline Kashmir . & Myotis longipes & murinus & Nycteribia & 一 & Garnham \\
\hline $\begin{array}{ll}\text { New } & \mathrm{He}- \\
\text { brides } & \ldots\end{array}$ & Min. australis & melanipherus & 一 & 一 & McGhee \\
\hline Australia . & Min. blepotis & melanipherus & Penicillidia & 一 & $\begin{array}{l}\text { McKerras } \\
\text { McMillan }\end{array}$ \\
\hline$\gg$ & Hipposideros sp. & murinus & - & - & $»$ \\
\hline$\gg$ & Nyctophilus sp. & murinus & 一 & 一 & 》 \\
\hline$\gg$ & Eptesicus & murinus & - & 一 & » \\
\hline Africa $\ldots$ & $\begin{array}{l}\text { Min. } \\
\text { inflatus etc. }\end{array}$ & melanipherus & - & 一 & $\begin{array}{l}\text { Anciaux de } \\
\text { Faveaux }\end{array}$ \\
\hline Africa $\ldots$ & Rhinolophus & ? murinus & 一 & 一 & $\begin{array}{l}\text { Anciaux de } \\
\text { Faveaux }\end{array}$ \\
\hline
\end{tabular}

* Corradetti (1936) found short and thick sporozoites $(6,3 \times 1,8 \mathrm{~m} \mu)$ in 2 examples of Listropoda from the Roman Campagna. 
Table I (Continued)

\begin{tabular}{|c|c|c|c|c|c|}
\hline Place & Bat & $\begin{array}{l}\text { Polychro- } \\
\text { mophilus }\end{array}$ & Nycteribiid & $\begin{array}{l}\text { E.E. } \\
\text { schi- } \\
\text { zonts }\end{array}$ & Author \\
\hline Africa $\ldots$ & $\begin{array}{l}\text { Rhinolophus } \\
\text { landeri }\end{array}$ & $?$ murinus & 一 & - & $\begin{array}{l}\text { Adam and } \\
\text { Landau }\end{array}$ \\
\hline » & $\begin{array}{l}\text { Triaenops } \\
\text { persicus }\end{array}$ & $?$ murinus & 一 & - & $\gg$ \\
\hline 》 & Min. minor & $\begin{array}{l}\text { melani- } \\
\text { pherus }\end{array}$ & $\begin{array}{l}\text { Penicillidia } \\
\text { fulvida }\end{array}$ & + & $\gg$ \\
\hline$\gg$ & Rhinolophus & murinus & - & + & $\begin{array}{l}\text { Ashford et } \\
\text { Bray }\end{array}$ \\
\hline California & $\begin{array}{l}\text { Antrozous } \\
\text { pallidus }\end{array}$ & murinus & - & 一 & Wood \\
\hline Texas $\ldots$ & $\begin{array}{l}\text { Pipistrellus } \\
\text { hesperus }\end{array}$ & murinus & 一 & - & Wood \\
\hline Brazil $\ldots$ & Glossophaga & murinus & - & 一 & Deanes \\
\hline$\gg$ & Myotis nigricans & deanei & Basilia & - & Garnham et al. \\
\hline
\end{tabular}

\section{New Records and Redescriptions}

\section{Kashmir.}

In the course of the British Karst Expedition to the Himalayas in 1970, Geoffrey le Patourel captured specimens of Myotis longipes in the Bhamajo cave near Achabal in Kashmir at an altitude of $1730 \mathrm{~m}$. The temperature inside the cave in October was $18{ }^{\circ} \mathrm{C}$. One bat out of 19 collected showed scanty parasites of a Polychromophilus type in the blood films. The gametocytes were all oval (fig. 1) and when mature no trace of the erythrocyte was visible. In slightly immature forms, one end of the parasite was straight instead of curved. The pigment granules were particularly heavy, black, and sometimes bar-shaped. Occasionally a large vacuole was present in the cytoplasm. The usual male and female morphological distinction was noted. The mean length of the male was $5 \mu$ and breadth $4 \mu$; of the female, the length was $6 \mu$ and breadth $4 \mu$. Sections of the liver, spleen and kidneys of the infected bats were stained and examined but no exoerythrocytic schizonts were detected.

Nycteribiid flies were collected from the infected bat and were fixed in formalin. Sections were made and in two flies sporozoites of a stumpy type were found in the haemocoelomic cavity. The sporozoites in section were straight or curved and measured about $7 \mu$ in length. Their ends were rounded and the oval nucleus was situated off centre (fig. 2). 

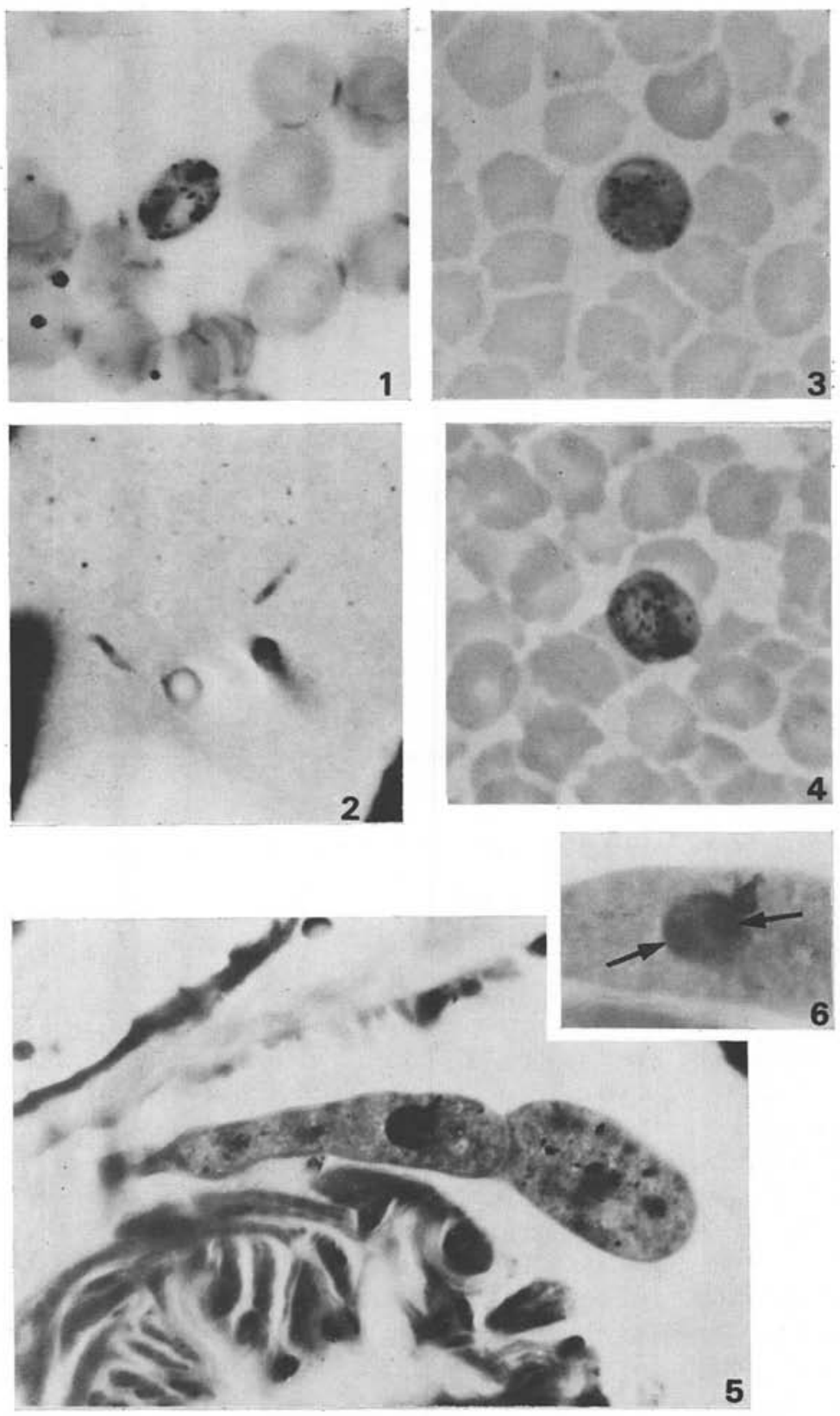

FIG. 1. - Polychromophilus murinus from Kashmir. Microgamtocyte, showing oval shape and prominent pigment granules. $\times 2000$ (Giemsa). - FIG. 2. Two sporozoites of P. murinus in section of Nycteribiid fly. $\times 2000$ (Giemsa). - FIg. 3. - Polychromophilus murinus (?), from Ethiopia. Microgametocyte, showing round shape. $\times 2000$ (Giemsa). - Fig. 4. - Polychromophilus murinus (?), from Ethiopia. Macrogametocyte, showing round shape. $\times 2000$ (Giemsa). - Fig. 5. - Lankesteria galliardi. Two trophozoites in association in section of Nycteribiid fly. $\times 1000$ (Giemsa). - FIG. 6. - Lankesteria galliardi. Nucleus of gregarine in fig. 5, enlarged to show 2 karyosomes indicated by arrows. $\times 2000$ 
In addition to the malaria infection, several flies of this batch showed a heavy infection of an acephaline gregarine, the first record of these parasites in nycteribiids (fig. 5). The dimensions in section were as follows:

Length $53 \mathrm{~m} \mu$ (or more) ; breadth at nucleus $9 \mathrm{m \mu}$; width of nucleus $7 \mathrm{~m} \mu$. The nucleus was unusual in possessing two prominent and darkly staining karyosomes (fig. 6). The cytoplasm was granular, reticulate or finely vacuolated and was enclosed in a thick, eosinophilic membrane, best seen at the tapering and sharply pointed extremity. The other end was rounded. The gregarines were sometimes in association end to end; in other examples the vermicular shape was lost when many trophozoites lay massed together. No other stages were found.

Although the discovery of this parasite is limited to the trophozoite stage, the presence of a gregarine in a new family of the Diptera (Hippoboscidae) is of interest. Dipterous insects of other families are often infected with gregarines of the genus Lankesteria, and the parasite found in this nycteribiid is accordingly named Lankesteria galliardi sp. nov. Its formal annotation is as follows:

Locality: Achambo, Kashmir.

Host: Nycteribia dentata on Myotis longipes.

Description: Trophozoites elongated $(50 \mathrm{~m} \mu)$ or more in length, enclosed in thick membrane, possessing nucleus with 2 karysosomes; one end pointed.

Date of collection : August, 1970.

\section{United States.}

Dr. Sherwin Wood kindly put at the writer's disposal his collection of blood films of bats from Texas and California, in which he had recorded the presence of malaria parasites in 1952 .

In a male Antrozous pallidus, collected in 1951 in the San Joaquin Experimental Range, in California, a light infection of Polychromophilus was found. The microgametocytes were subspherical, 8-8.5 $\mathrm{m} \mu$ in diameter, pinkish in colour, and several centrioles were present; the pigment was inconspicuous. The macrogametocytes were of similar shape, up to $9 \mathrm{~m} \mu$ in diameter, with a small nucleus and no centrioles; abundant pigment in irregular grains was distributed through the cytoplasm. No signs of the erythrocyte were seen. This parasite appears to be longer and more oval than Po. deanei, and the pigment in the female is more abundant. Wood found similar parasites in pipistrelles in Texas, but Myotis was consistently negative.

\section{Ethiopia.}

Ashford discovered infections in the blood of Rhinolophus sp. in caves in the highlands of Ethiopia, and concluded that the parasite was Polychromophilus because he found scanty small exoerythrocytic schizonts in smears of the liver. This example illustrates the difficulty of identification, as the correct diagnosis may well be 
Nycteria sp. The gametocytes (figs. 3 et 4 ) are round instead of oval and the pigment granules are small; moreover, like $N$. congolensis they provoke enlargement of the erythrocyte, whose envelope persists. The «schizonts in the liver may possibly have been portions of a broken schizont of a Nycteria type.

\section{Discussion}

The primary requirement for zoogeography is the adequacy of the survey, and it is well appreciated that many maps purporting to illustrate the distribution of an organism merely represent the places where the zoologist has worked. The records mentioned in this paper indicate however the facility with which Polychromophilus is encountered in the Old World. The problem is complicated in the Old World by the occurrence in insectivorous bats of closely related haemosporidian parasites.

The vertebrate hosts are practically all vespertilionids, and Miniopterus and Myotis continue to be the genera from which most records of infection emanate. The former has a limited number of species and Min. schreibersii heads the list of infections; the genus is confined to the Old World and to the warmer parts of the Palaearctic, Ethiopian, Indo-Malaysian and Australian regions. Myotis on the other hand is completely cosmopolitan occurring throughout the eastern and western hemispheres to the limit of tree growth. It has many species and several of these in the Old World are commonly infected, the incidence being affected by climate and season.

Nycteribiid flies are faced with few hostile elements, and unlike strebliids easily survive the season of hibernation of the bat. The actual species of vector has been determined in only a few instances, and these are shown in Table 1. Ectoparasitism of the vespertilionid bats is almost universal. Basilia in the New World and Penicillidia in the Old World appear to be the chief agents concerned in transmission.

The three components of the infections - bats, nycteribiid and Polychromophilus — almost constitute a single entity, and they possibly evolved together from an early age. The rarity of the infection in the Americas presents an interesting problem, and four possibilities may be discussed.

1. Parallel evolution of all three components seems improbable.

2. Vespertilionid bats are thought to have reached North America via the Behring Straits and to have colonised that continent, evolving into new genera and species as they travelled to the South. The migrations probably took place in pre-glacial periods, and it may be supposed that the bats were accompanied by their ecto and endo-parasites. The present day distribution of the infection in temperate and tropical climates indicates its ability to survive under different conditions.

3. The complex of bat and its parasites may have reached the New World during continental drift, but the dating of this process, at a hundred million or more years ago, makes this theory unlikely in view of the date of the evolution of these organisms, which was probably later. 
4. Infected bats may have been transported across the Atlantic Ocean in historical times, either blown across or more probably, taken across in the holds of ships.

The second and third theories appear to be less valid than the fourth. If the infected bats had reached the New World at a remote age, the infection, by now, should be widely disseminated; if the introduction were more recent, a rare and focal distribution would be expected. The limitation of the infection to Pará, California and Texas fits in best with the fourth theory of the arrival of infected bats in perhaps the last thousand years.

Against the theory of a recent introduction is the widespread distribution of Trypanosoma vespertilionis in South America, where, according to Hoare (1971), this parasite occurs in Myotis nigricans from Argentina in the South, through Brazil to Colombia. This parasite is equally common in the Old World, where presumably it originated. Other cosmopolitan blood parasites exist, of which three common examples are Trypanosoma lewisi in rats transmitted by fleas, Haemoproteus columbae in pigeons transmitted by Lynchia, and Plasmodium relictum in passerine birds transmitted by mosquitoes. Owing to the migratory habits of these hosts, the rapid spread of the infection after recent introduction would be a likely event - as is known to have occurred in regard to yellow fever and plague which were brought from Africa to the New World within the last few centuries.

The arbitrary division of Polychromophilus into two main species is unsatisfactory; minor differences occur in the gametocytes of various bats, but until complete life cycles of these parasites are elucidated and experimentally verified, their classification must remain provisional. At the beginning of the Discussion of this paper, I mentioned the adequacy of he Survey as the primary basis of zoogeography; at the close, I refer to the correct identification of the organisms as another necessity. This is lacking at present, and this communication can only be regarded as a preliminary attempt to solve the problem.

\section{References}

Adam (J. M.), 1971. - Proc. lst European Conference of Parasitology, Rennes.

Corradetti (A.), 1936. - Ann. Igiene, 46, 444.

Deane (L. M.) et Deane (M. P.), 1961. - Rev. Inst. Med. trop., S. Paulo, 3, 107.

Dew (B. B.) and McMillan (B.). - Parasitology, (in press).

Dionisi (A.), 1899. - Atti. Soc. Studi Malar., 1, 133.

DunN (F. L.), 1965. - Malayan Nat. J., 19, 75.

Ewers (W. H.) (Pers. Comm.).

Eyles (D. E.), Dunn (F. L.) and Liat (L. B.), 1962. - Med. J. Malaya, 17, 87.

Garnham (P. C. C.), 1953. - Riv. Malariol., 32, 149.

-, 1966. - Malaria Parasites and other Haemosporidia, Oxford : Blackwell Scientific Publications.

- and Heisch (R. B.), 1953. - Trans. Roy. Soc. trop. Med. Hyg., 47, 357. 
Garnham (P. C. C.), Lainson (R.) and Shaw (J. J.), 1971. - Mem. Inst. Oswaldo Cruz., 69, 119.

HosRe (C. A.), 1971. - The Trypanosomes of Mammals, Oxford : Blackwell Scientific Publications.

Killick-Kendrick (R.), (Pers. Com.).

Landau (I.) and Adam (J. P.), 1973. - Trans. Roy. Soc. trop. Med. Hyg., 61, 6.

De Mello (F.) and De SA (D.), 1916. - Ind. J. med. Research, 3, 731.

Mer (G. G.) and Goldblum (N.), 1947. - Nature, 159, 444.

Schingarev (A. J.), 1906. - Arch. Sci. biol. St. Petersbourg, 12, 182.

VAssal (J. J.), 1907. - Ann. Inst. Pasteur, 21, 224.

Wood (S. F.), 1952. - J. Parasit., 38, 85. 